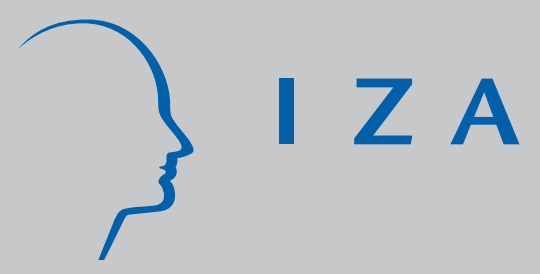

IZA DP No. 2586

Intra-household Gender Disparities in Children's Medical Care before Death in India

\author{
Abay Asfaw \\ Stephan Klasen \\ Francesca Lamanna \\ J anuary 2007
}




\title{
Intra-household Gender Disparities in Children's Medical Care before Death in India
}

\author{
Abay Asfaw \\ International Food Policy Research Institute
}

Stephan Klasen

Göttingen University and IZA

Francesca Lamanna

Göttingen University
Discussion Paper No. 2586
January 2007

IZA
P.O. Box 7240
53072 Bonn
Germany

Phone: +49-228-3894-0

Fax: +49-228-3894-180

E-mail: iza@iza.org

\begin{abstract}
Any opinions expressed here are those of the author(s) and not those of the institute. Research disseminated by IZA may include views on policy, but the institute itself takes no institutional policy positions.

The Institute for the Study of Labor (IZA) in Bonn is a local and virtual international research center and a place of communication between science, politics and business. IZA is an independent nonprofit company supported by Deutsche Post World Net. The center is associated with the University of Bonn and offers a stimulating research environment through its research networks, research support, and visitors and doctoral programs. IZA engages in (i) original and internationally competitive research in all fields of labor economics, (ii) development of policy concepts, and (iii) dissemination of research results and concepts to the interested public.
\end{abstract}

IZA Discussion Papers often represent preliminary work and are circulated to encourage discussion. Citation of such a paper should account for its provisional character. A revised version may be available directly from the author. 


\section{ABSTRACT \\ Intra-household Gender Disparities in Children's Medical Care before Death in India*}

The excess female mortality in India and other South Asian countries is no longer contentious. Less known are the reasons for such excess female mortality in the country. In this study, we argue that intra-household gender-discrimination in receipt of medical attention can be one of the most important factors for the unbalanced sex ratio in the country. The 52nd Indian National Sample Survey, which collected for the first time detailed verbal autopsies of deceased persons, is used in the analysis. Place of death, which indicates whether a person get medical help immediately before her/his death, is used as a health indicator variable. The multinomial logit results show that keeping all other factors constant, girls are 1.7 percent less likely to die in hospital than their brothers. The coefficients of different interaction variables also reveal that the probability of infant and very young girls with live female siblings to die in hospital is extremely low. The robustness of the results is also checked using different indicators. The results confirm that girls are highly discriminated in access to hospital treatment and in the number of times being hospitalized before their death compared to boys. Therefore, in addition to the current effort of the government to control sex-selective abortions, efforts should be made to reduce the current intra-household gender-disparities in getting medical care at least for life threatening illnesses.

JEL Classification: D63, I12, J16

Keywords: gender discrimination, access to health care, place of death, India

Corresponding author:

Stephan Klasen

Department of Economics

University of Göttingen

Platz der Göttinger Sieben 3

37073 Göttingen

Germany

E-mail: sklasen@gwdg.de

\footnotetext{
* We want to thank participants at seminars in Washington and Göttingen for helpful comments and discussion. Funding from the German Science Foundation in support of this work is gratefully acknowledged.
} 


\section{Introduction}

While the magnitude varies from one study to another (depending on the data and the standard sex ratio reference level used), the excess female mortality in India and other South Asian countries is no longer contentious (Sen, 1992; Coale, 1991; Klasen, 1994). It is also only in this part of the world that the life expectancy of women at birth is lower or equal to men, despite the biological advantage of women as a group to live longer than men (Hart, 1988; UNDP, 1995; Waldron, 1995; WHO, 1998; Gjonca et al., 1999; Kalben, 2002). Even for infants (aged less than one) the mortality of girls was 1.3 times higher than boys in India (Khanna et al., 2003). This fact seems paradoxical since these countries have relatively high economic performances, including high per capita income, high medical personnel, and medical facilities population ratios, compared to most of the countries in Sub-Sahara Africa. The non-responsiveness of this discrimination to the improvement in the economic status of households (Hill and Upchurch, 1995; Kurz and Johnson-Welch, 1997) also makes the issue of excess female mortality a serious concern in this region.

Factors related to social, cultural, familial, behavioural, and other discriminatory behaviour of households, communities, and sometimes governments against girls and women can be some of the reasons for the higher than expected female mortality in South Asian countries. Therefore, there is a crucial need to investigate factors and mechanisms that jeopardised the biological advantage of women to live longer than men and consequently produced millions of 'missing women' and an unbalanced sex ratio in this part of the world.

Several factors including sex-selected abortion; gender discrimination in nutrition especially among young children; discrimination in access to health care, labour markets, education, and other opportunities; and intra-household/ community discrimination against women/girls are hypothesized in the literature for this excess female mortality in the region. Gender discrimination in intra-household food distribution (nutrition) has long been identified as a major factor for excess female mortality in the region. However, several recent findings reveal that there is no significant evidence of gender discrimination in nutrition among children (Chaudhury, 1987; Das Gupta, 1987; Gopalan, 1987; Basu, 1989; 1993; Walker and Ryan, 1990; Kurz and Johnson-Welch, 1997; Hazarika, 2000). Very recently, sex-selective abortion (Booth, et al., 1994; Khan et al., 1996; Sudha \& Arnold, 1999; Arnold 2002) has received greater attention as one of the major factors for the unbalanced sex ratio in the region. In this study, we argue that intrahousehold discrimination in health care behaviour of households against girls can be one of the most important factors for the unbalanced sex-ratio in the region.

Various authors examined gender discrimination in the provision of health care services. Despite some researchers could not find statistically significant gender differences in access to some types of health care services (Jatrana, 2003), there are several evidences that show gender discrimination in health care utilization in India, Bangladesh and Pakistan (Rajeshwari, 1991; Singh et al., 1962 ; Aziz, 1977 ; Chen et al., 1981; Miller 1981; Murthy, 1982 ; Das Gupta, 1987; Chaudhury, 1988; Wadley, 1993; Greenspan, 1994; Sood and Nagla, 1994; Rajeshwari, 1996; Kurz and Johnson-Welch, 1997; Gangadharan and Maitra, 2000).

This study provides fresh evidences on intra-household gender discrimination against girls (aged from 1 day to nine years) in getting medical attention before their 
death in India. Unlike most of the previous studies which focused on small sample sizes and on illness symptoms, this study used nationally representative data set and examined the existence and magnitude of gender discrimination in getting medical attention at the last critical time of life ${ }^{1}$. More specifically, the study examines whether girls were discriminated against in getting medical help before their death. We argue that although mortality differences between girls and boys can be the result of biological factors, disparity in getting medical attention between girls and boys before death reveals gender discrimination.

Out of several indicators that measures medical attention before death such as causes of death, whether medical attention was sought before death, number of times hospitalized, etc, we used place of death variable as a main indicator for various reasons. First, in contrast to developed countries where almost everybody gets medical attention before death and where to die is a matter of choice ${ }^{2}$, place of death (in hospital, at home, at nursery, etc.) is a crucial indicator of whether deceased individuals got proper medical attention before their death in developing countries like India (Gupta and Sankar, 2002). Second, the one year recall period used in the national sample survey (see next section) is less likely to affect the reliability of the place of death information compared to other indicators.

The study also focuses on infants and children (aged from one day to nine years) because compared to adults and teenagers; the chance of children to get medical care totally depends on the decision of parents. This helps us to clearly see the level intrahousehold gender discrimination in seeking medical help. Focusing on children will also avoid biological differences and gender differential in exposure to risks and deaths (occupation, pregnancy, gender violence, death due to old age, etc.) that may potentially affect the chance of getting medial care and consequently the place of death. The imbalance in the proportion of deaths between girls and boys is also high for this age group in India (BMJ, 2002; Khanna, et al., 2003).

Out of several South Asian countries the study focuses in India for various reasons. First, the country has the highest share of missing women in the world (Klasen and Wink, 2002) and currently the problem has reached a critical point where it affects the sex balance (UNICEF, 1990; WHO, 1992; Pande, 2000). Second, while female mortality is rare in infancy and early neonatal period (WHO, 2000), it is higher for females than for males in India (WHO, 2000, BMJ, 2003). Third, as we shall explain soon, India has a data set that can be used to address the issue of gender discrimination in getting health care before death.

The remaining part of the paper is organized as follows. Section two presents the data source and measurement of variables and section three explains the methodology used in the study. Finally, section four and five present the results and conclusion of the study.

\section{Source of data and Measurement of Variables}

The Indian National Sample Survey (NSS) data were used in this study. Since 1950, the National Sample Survey Organization of India has been collecting major information on socio-economic conditions of the population as well as economic and operational features of informal enterprises and establishments (Saha, 2002). In this study the $52^{\text {nd }}$ round NSS conducted between July 1995 and June 1996 were used. Two-stage stratified 
sampling procedure was adopted. At the first stage, 7,663 rural villages and 4,991 urban blocks were identified all over the country and at the second stage 71,284 rural and 49,658 urban households were surveyed.

The $52^{\text {nd }}$ round collected information on utilization of health care services, morbidity, problems of aged persons, and participation in education. For the first time in the long history of the NSS, the $52^{\text {nd }}$ round also collected detailed information about deceased family members. Detailed verbal autopsies including name and sex; age at death; time elapsed since death; cause of death; place of death; medical attention before death; whether hospitalized during last 365 days; and number of times hospitalized was collected. The recall period was one year before the survey.

From Schedule 25.0 of the $52^{\text {nd }}$ NSS, place of death (at home, in public hospital, in government hospital, during transport, at other places) was selected as a main indicator of getting medical attention before death. This variable is expected to measure the real concern of parents to save the lives of their children. Various factors that may influence the place of death of children such as age and sex of the child; location (urban/rural), income (approximated by monthly household expenditure), family size and composition, and social status (whether or not the household belongs to scheduled tribe or scheduled caste) of the household; and age, education, and sex of the household head, etc., were used as explanatory variables. The definition and descriptive statistics of the variables are presented in Table 1. Deceased children and infants aged from one day to nine years were considred.

\section{Methodology}

The probability of observing nominal outcomes such as places of death can be modelled using various nominal outcome models. In this study, a multinomial logit model was used to examine the determinants of dying at different places. Other nominal outcome models such as conditional or mixed logit models could not be used because information on the characteristics of the outcome variables was not collected. The survey provided five places of death: at home, during transport, in government hospitals, in private hospitals, and at other places. Then, the likelihood of a child to die in any of the above places, say place $j$ can be presented as:

$$
\operatorname{Pr}\left(y_{i}=j\right)=f\left(X_{i}, Z_{i}\right), j=1, \ldots, m
$$

Where $X_{i}$ is a vector of individual characteristics of dead child $i$ such as sex, age at death, $Z_{i}$ is a vector of household level variables of child $i$ such as education, age, and sex of the household head, income, social status, location, and the like.

Based on a multinomial model, the probability of child $i$ will die at place $j$ is given by

$$
\operatorname{Pr}\left(y_{i}=j\right)=\frac{\exp \left(\beta_{j}^{\prime} X_{i}+\gamma_{j}{ }^{\prime} Z_{i}\right)}{\sum_{l=1}^{m} \exp \left(\beta_{l}{ }^{\prime} X_{i}+\gamma_{l}{ }^{\prime} Z_{i}\right)}
$$

Where $\beta$ and $\gamma$ are vector of parameters to be estimated. Note that since information on outcomes' characteristic is not available, all the explanatory variables represent the characteristics of child $i$ or her/his family and therefore vary over the outcomes. If there is 
any gender discrimination in the place of death, the coefficient of the sex variable should be statistically significant.

\section{Results}

Descriptive Analysis

Out of 3,506 individuals deceased during one year before the survey, 26 percent were children and infants aged from one day to nine years. From the total deceased children, infants (less than one year old) accounted for 68.35 percent followed by children aged between 1 and 4 (20.00 percent) and 5 and 9 (11.65 percent). Overall, 67.58 percent of children died at home, 26.15 died in hospital and 2.31 and 3.96 percent died during transport and other places, respectively. Various factors including accessibility of medical facilities, area of residence, income and education of parents might affect the place of death of children. Table 2 presents some descriptive statistics. As expected, for all age groups rural children were more likely to die at home compared to urban children and the differences were statistically significant for young children (Person $\chi^{2}$ test). For instance, while 41 percent of infants had a chance of dying in hospitals in urban areas, only half of them had this chance in rural areas.

Though not statistically significant $\left(\chi^{2}\right.$ test) at 5 percent level, 36.84 percent of children from the richest quintile died in hospital compared to 22.54 percent children from the poorest quintile. In general income did not have important influence on the place of death of children. This was unexpected result since children from rich households were expected to die at hospitals than children from poor households.

The last column of the table shows gender differences. Under normal circumstances, there should not be differences in the place of death for girls and boys. However, the table reveals that at all age groups girls were more likely to die at home than boys and the differences were statistically significant in the case of infants and 1-4 years old children. Boys were also more likely to die in hospital than girls at all age groups. Overall 33 percent of boys died in hospitals compared to only 19 percent of girls. The difference was much higher in the case of infants. While $35 \%$ of boys died in hospital only 17 percent of girls had this chance.

This pattern remained the same even after controlling the place of residence and income of households as shown in Figs. 1 and 2. In both rural and urban areas girls were less likely to die in hospital than boys and the differences were very striking in the case of infants. In urban areas 31 percent of infant girls died in hospital compared to 48 percent boys. In rural areas the discrimination was even worse. Despite 30 percent of infant boys died in hospital, only less than half of infant girls got this chance. Similar pattern was observed across different income quintiles. Except for the age group 5-9, boys were more likely to die in hospital than girls for all income quintiles. The last two rows of table 2 also indicate that girls with live female siblings (younger than 15 years old) were the most disadvantaged groups in getting medical help before their death.

All results indicate that girls, especially infant girls, were more likely to die at home without getting medical attention at the last critical time of their lives and this was true both in urban and rural areas, and across different income groups. Girls with sisters younger than 15 years of age were particularly vulnerable. Therefore, discrimination in 
seeking medical help against infant girls might be one possible explanation for the imbalance sex ratio in the country.

\section{Multinomial logit results}

A multinomial logit model was estimated to determine whether gender affected the likelihood of place of death of children. Before presenting the final results of the model, we examined various specification and related issues. First, we test for combining any of the five outcomes (places of death). An outcome $j$ is said indistinguishable with outcome $k$, if none of the independent variables significantly affect the odds of outcome $j$ versus outcome $k$ (Long and Freese, 2003). In the light of the loglikelihood test results and common sense, government and private hospital and home and other outcomes were combined and three mutually exclusive places of death were created (at home, in hospital, and during transport). Second, we test for the independence of irrelevant alternative (IIA) assumption of the multinomial logit model using both Hausman-McFadden and SmallHsiao tests. Both tests showed that IIA assumption holds, i.e., odds (Outcome-j vs Outcome-k) are independent of other alternatives. Third we examine the variance inflation factors (VIF) to test for the existence of multicolinearity. The computed VIF was 1.06 indicating absence of any significant multicolinearity.

Two individual variables, viz., sex and age of the deceased child, eight household level variables viz. sex, age, age square, and education level of the household head; number of live female siblings younger than 15 years of age, income, location, and social status of the household were included in the model (see table 1 for definition and descriptive statistics of these variables). In addition to individual and household level variables, 77 district level dummy variables were included in the regression to take into account unobserved district level factors that might affect the place of death of children.

The results of the multinomial model are presented in Table 3. Death at home (versus death in hospital and during transport) was the reference (comparison or base) category. The coefficients of the district level dummy variables were omitted for brevity of presentation. The LR $\mathrm{chi}^{2}$ test is significant rejecting the hypothesis that all of the regression coefficients across both models are simultaneously zero. The McFadden's pseudo $\mathrm{R}^{2}$ is 0.22 . Since direct interpretation of the coefficients is difficult, marginal coefficients were computed and presentment for statistically significant variables.

Age and sex of the household head took the expected negative sign indicating that children in older and female headed households were less likely to die in hospital or during transport than children in young and male headed households. However, both variables were not statistically significant at the ten percent level. Income also took the expected positive sign but was not statistically significant in explaining place of death. Though consistent with the descriptive statistics, this result is counter intuitive. However, similar results were reported by other authors. For instance, Khanna et al. (2003) found that poverty did not explain sex discrimination in infants' death in urban India. Kurz and Johnson-Welch (1997) also concluded that increasing household income alone might not be sufficient to reduce gender discrimination in India.

As expected, children in urban areas were more likely to die in hospital or during transport than at home. Education level of the household head was the other most important variable that determined the place of death of children. Children with educated 
household heads (primary and above education) were 1.63 and 0.01 percent more likely to die in hospital and during transport, respectively than children with less than primary school household head, all other variables remaining constant. However, the interaction between education and gender variables was insignificant (not shown in the table) indicating that education did not affect gender differences in the place of death of children. Consistent with the descriptive analysis, the probability of dying outside home increased in child age, ceteris paribus. Keeping all other variables constant, a one year increase in the age of a child decreased the likely of dying at home by 0.68 percent. Other variables such as social status, family size, number of female siblings in the household did not have statistically significant impact on the place of death.

Our main interest variable, gender, took the expected positive sign in the case of dying at home and negative signs in the case of dying in hospital and during transport and was statistically significant in all cases. The marginal coefficient of the home outcome showed that all other variables remaining constant, girls were 1.8 percent more likely to day at home than boys. In other words, boys were 1.8 percent more likely to die in hospital and 0.01 percent during transport than girls keeping all other factors constant. This clearly indicates that controlling for all other factors, girls were less likely to get medical attention immediately before their death than boys.

The effect of various factors such as age of the deceased child and number of female siblings in the household on the place of death of children may vary by gender. We hypothesized that young girls and girls with female siblings were less likely to get medical attention before death than boys. We used two methods to examine these possibilities. First, we plot the probability of dying at different places as a function of age of the deceased child and number of female siblings in the household by gender keeping all other factors constant at their mean values. Second we created interaction variables between age and gender and number of female siblings and gender and add these interaction variables in the model.

Figure 3 presents the probability of dying at home, in hospital, and during transport as a function of age of the deceased child by gender keeping all other variables constant. As expected, at all age levels girls were more likely to die at home and less likely to die in hospital or during transport than boys. However, consistent with previous results, their probability of dying in hospital or during transport increases as their age increases. Figure 4 portrays the probability of dying at different places as a function of number of female siblings in the household by the gender of the deceased child. The figure shows that, all other things remaining constant, as the number of female siblings in the household increased the chance of girls to die at home increased significantly compared to their brothers. Girls with female siblings had also small chance of dying in hospital or during transport compared to boys and this small chance significantly decreased as the number of female siblings in the household increased.

Interaction variables between gender and age and gender and number of female siblings in the household were also included in the multinomial estimation and the results are presented in Table 4 . The coefficients of all the interaction variables took the expected signs and were statistically significant in most of the cases. The interaction between age and gender variable showed that as age increased the likelihood of a girl to die during transport (compared to dying at home) increased, all other things remaining constant. More interestingly, after controlling gender and other variables in the model, 
girls with female siblings were less likely to die in hospital than girls with no or few female siblings and boys.

However, as pointed out by Ali and Norton (2003) and Norton (2004), the exact interpretation of interaction terms in nonlinear models such us ours is not straight forward. Therefore, we use graphs to examine the impact of the interaction terms and the results are presented in Figures 5 and $6^{3}$. These figures are expected to give more precise picture (than the one presented in Figures 3 and 4) since the interaction effects are included. Figure 5 portrays the probability of dying at home, in hospital, and during transport as a function of age of the deceased child by including the interaction effect between age and gender of the deceased child. Consistent with figure 3, infants of both sexes were more likely to die at home than children. At the same time the probability of girls to die at home was higher and to die in hospital was lower than boys at all age levels. In contrast to Fig. 3, Fig. 4 clearly showed that these differences decreased as the age of the child increased.

Fig. 6 also showed very interesting results. The probability of boys to die at home decreased as the number of female siblings in the household increased while the probability of girls to die at home significantly increased as the number of female siblings increased. The probability of girls to die in hospital also significantly decreased as the number of female siblings in the household increased. These results can be clearly seen by the funnel shape of the first two graphs of Fig. 6 . However, the number of female siblings in the household was less likely to affect the difference in the probability of dying during transport between boys and girls.

All these results clearly indicate that there is significant gender discrimination in place of death in India. Boys were more likely to die in hospital and during transport to hospital than girls and girls were more likely to die at home. Particularly, infant girls with female siblings were unlikely to get medical help at the last critical time of their lives. This clearly shows that female infanticide can be one of the most important factors for the current imbalanced sex ratio in the country. Therefore, the focus of policy makers should not be limited to reduce medical termination of pregnancy based on fetal sex, but should also focus on the health care demand behaviour of households to ensure equality in medical access between boys and girls especially at their earlier life. 


\section{Robustness test}

Place of death is a good indicator of gender discrimination in access to medial care in developing countries especially for children. However, dying at home may not necessarily imply deprivation of medical attention before death. Therefore, we used three additional indicators to examine gender discrimination in getting medial help before death in India. First, we examined whether the deceased child did not receive any medical attention before death. Overall 28 percent of deceased children did not get any type of medial help before death and there was no statistically significant difference between boys and girls. Second, we examined whether the child was hospitalized for treatment before death during last 365 days before the survey. The data showed that 38 percent of boys hospitalized before their death while only 26 percent of girls hospitalized before their death and the difference was statistically significant at less than one percent (Pearson $\chi^{2}$ test). Finally, we examined the number of times the deceased child was hospitalized during last 365 days preceding the day of the survey. On the average, boys were hospitalized 0.42 times while girls were hospitalized only 0.3 times.

We used the above three variables to examine gender discrimination in getting medical help before death. We used logit specification in the case of hospitalization and getting any medical help before death and OLS method in the case of number of times hospitalized before death. The results are presented in Table 5. In all models the gender variable took the expected sign though not statistically significant in the case of no any medical help before death ${ }^{4}$. The marginal coefficient of the gender variable in the case of hospitalization before death indicated that, all other things remaining constant, the probability of girls to be hospitalized before their death was 12 percent less than boys. The OLS result also revealed that the average number of times girls were hospitalized before their death was 0.11 less than that of boys (the average was 0.36 times). All these results confirm that there was noticeable and statistically significant difference by sex of the child in getting medical help before death. Overall, girls were more likely to be denied medical attention before their death than boys. 


\section{Conclusion}

The excess female mortality in India and other South Asian countries is no longer contentious. The ambiguous and controversial things are the reasons for such excess female mortality in the country. The non-responsiveness of this excess female mortality to the improvement in the economic status and educational level of households also makes the issue more complicated. Several factor including female feticide, gender discrimination in nutrition, health care, labour markets, education, and other opportunities are cited in the literature for this excess female mortality in the region. Using unique verbal autopsies information collected in the $52^{\text {nd }}$ Indian National Sample Survey and econometric models, this study provides new evidences on intra-household gender discrimination against girls in getting medical attention before death. We argue that compared to mortality differences between girls and boys which can be partly explained by biological factors, disparities in getting medical attention before death reveal gender discrimination potentially attributed to behavioural factors.

From several indicators that measure medical attention before death, we used place of death variable as a main indicator. Unlike developed countries where place of death is a matter of choice, in developed countries like India place of death is a crucial indicator of access to medical care at last critical time of life. Particularly in the case of non-adults it measures the real concern of parents for their children. The study also focused on infants and children (aged from one day to nine years) since their chance of getting medical help totally depends on the decision of their parents. This helps us to clearly see the level of intra-household gender discrimination in the health care decision of households.

The multinomial logit results showed that girls were highly discriminated against in getting medical help immediately before their death. The marginal coefficient of the gender variable showed that boys were 1.7 percent more likely to die in hospital and 0.01 percent during transport than their sisters, ceteris paribus. The coefficients of the interaction between age and gender and number of female siblings and gender also clearly pointed out part of the girls which were highly vulnerable to such discrimination. Controlling for all other factors, the probability of very young girls with live female siblings to die in hospital was extremely low and this probability decreased significantly as the number of live female siblings in the household increased. The robustness of the results was also tested using three different indicators that measures access to health care before death. Except in the case of 'any medical attention before death' indicator, the results of the two indicators confirmed the existence of statistically significant gender discriminations. Boys were more likely to be hospitalized before their death and the average number times boys were hospitalized before their death was 0.11 higher than their sisters.

Generally, the results of this study clearly indicated that girls, particularly infant girls were discriminated in receiving medical attention before their death compared to their brothers. This implies that reducing this discrimination can help to improve the current falling sex ratio in the country. Therefore, in addition to the current effort of the government to enforce the law which makes fetal sex determination and medical termination of pregnancy on the basis of fetal sex illegal, more should be done to improve the medical access of girls at least for life threatening sicknesses to the level of their

brothers. This action coupled with reducing female foeticide may help to improve the 
declining sex ratio in the country. Looking at future research work on this topic, it would be useful to examine the type, spatial variation (across different regions and between rural and urban settings), and dynamic (through time) of intra-household gender disparities and their relationship with the current imbalance in sex ratios in the country. 


\section{References}

Arnold, A., Kishor, S., and Roy, T K. (2002). Sex-Selective Abortions in India. Population and Development Review 28(4): 759-

Axelsson, B. and Christensen SB. (1996). Place of Death Correlated to Sociodemographic Factors. A Study of 203 Patients Dying of Cancer in a Rural Swedish County in 1990. Palliat Med., 10(4): 329-335.

Bhuiya, A. and Streatfield K., 1991. Mother's education and survival of female children in a rural area of Bangladesh. Population Study, 45: 253-64.

BMJ, 2003. Girls are less likely to survive infancy in India. BMJ, Vol. 327, BMJ Publishing Group.

Booth, BE., Verma, M., Beri, RS. (1994). Fetal Sex Determination in Infants in Punjab, India: Correlations and Implications. BMJ, 309(12): 1259-1261.

Bourne, KL. and Walker, GM., 1991. The differential effect of mother's education on mortality of boys and girls in India. Population Study, 45: 203-19.

Chaudhury, R. H, 1988. Adequacy of child dietary income relative to that of other family members. Food and Nutrition Bulletin, 10 (2): 26-34.

Chen, L., E. Huq, and S. D'Souza, 1981. Sex bias in the family allocation of food and health care in rural Bangladesh. Population and Development Review, 7 (91): 55-70.

Claeson, M., E.R. Bos, T. Mawji, and I. Pathmanathan, 2000. Reducing Child Mortality in India in the New Millennium. Bulletin of the World Health Organization, 78(10):119299.

Coale, A.J., 1991. Excess female morality and the balnce of the sexes in the population: An estimate of the number of 'missing females'. Population and Development Rview, 17: 517-523.

Costantini, M., Balzi, D., Garronec E., Orlandini, C., Parodi, S., Vercelli, M., and Bruzzi, P. (2000). Geographical Variations of Place of Death among Italian Communities Suggest an Inappropriate Hospital Use in the Terminal Phase of Cancer Disease. Public Health, 114(1): 15-20.

Das Gupta, M., 1987. Selective discrimination against the female child in rural Punjab, India. Popul Dev Rev, 13(1): 77-100.

Feudtner, C., Silveria, MJ., Christakis, DA. (2002). Where Do Children with Complex Chronic Conditions Die? Patterns in Washington State, 1980-1998. Pediatrics, 109: 656-660.

Gangadharan, L. and Maitra, P. (2000). Does Child Mortality Reflect Gender Bias? Evidence from Pakistan. Indian Economic Review, 35(2): 113-131. 
Gjonca, A., C. Tomassini, and J. W. Vaupel, 1999. Male-female Differences in Mortality in the Developed World. MPIDR Working Paper WP 1999-009. Max-Planck-Institut für demografische Forschung.

Greenspan, A. (1994). Cultural Influences Demographic Behavior: Evidence from India. AsiaPacific Population and Policy, 28: 1-4.

Gupta, I. and Sankar, D. (2002). Medical Attention at Death: Evidence from India. Institute of Economic Growth, University of Enclave, Delhi 110007 India. Available at: http://iegindia.org/dis_ind_45.pdf

Harriss, B., 1989. Differential Child Mortality and Health Care in South Asia. Journal of Social Studies, 44: 112-123.

Hart, N., 1988. Sex, gender and survival: inequalities of life chances between European men and women. In A.J. Fox (ed): Inequality in Health within Europe. Aldershot: Gower.

Hazarika, G., 2000. Gender Differences in Children's Nutrition and Access to Health Care in Pakistan. The Journal of Development Studies, 37 (1): 73-92.

Hill, K., and D.M., Upchurch, 1995. Gender Differences in Child Health: Evidence from the Demographic and Health Surveys. Population and Development Review, 21(1): 127151.

Jatrana, S. (2003). Explaining Gender Disparity in Child Health in Haryana State of India. Asian Meta Centre Research Paper Series, no. 16.

Kalben, B.B., 2002. Why Men Die Younger? Causes of Mortality Differentials by Sex. SOA Monograph M-LI01-1. Society of Actuaries.

Khan, ME., Barge, S., and Philip, G. (1996). Abortion in India: An Over-View. Social Change, 26: 208-225.

Khanna, R., Kumar, A., Vaghela, JF., Sreenivas, V., and Puliyel, JM. (2003). Community based retrospective study of sex in infant mortality in India. BMJ 327(19):126-128.

Klasen, S., 1994. Missing Women Reconsidered. World Development, 22 (7): 1061-71.

Klasen, S., 1996. Nutrition, Health and Mortality in Sub-Saharan Africa: Is There a Gender Bias? The Journal of Development Studies, 32 (6): 913-32.

Klasen, S., and C. Wink, 2001. A Turning Point in Gender Bias Mortality? Discussion Papers in Economics 23, University of Munich, Department of Economics

Klasen, S., and C. Wink, 2003. Missing Women: Revisiting the Debate. Feminist Economics, 9.

Kurz, K.M. and C. Johnson-Welch, 1997. Gender Bias in Health Care among Children 0-5 Years: Opportunities for Child Survival Programs. A Review Paper Prepared for the BASICS Project. 
Lock, A. and Higginson, I. (2005). Patterns and Predictors of Place of Cancer Death for the Oldest Old. BMC Palliative Care, 4(6): 1-8.

Long, J.S. and Freese, J. (2003). Regression Models for Categorical Outcomes using Stata, Second Edition. College Station, TX: Stata Press. First edition, 2001.

Miller, MD. (1981). The Endagered Sex: Neglect of female Children in Rural North India. Ithaca, New York and London, Cornell University Press.

Mrhuri, P.K. and S.H. Preston, 1991. Effects of family composition on mortality differentials by sex among children in Matlab, Bangladesh. Population and Development Review, 17 (3): 415-434.

Murthi, M, A. Guio, and J. Drèze, 1995. Mortality, Fertility, and Gender Bias in India: A District-Level Analysis. Population and Development Review, 21(December): 745-82.

Murthy, N. 1982. Reluctant Patients-the Women of India. World Health Forum, 3(3):315-316.

Pande, P.R., 2000. Family composition effects on gender differentials in nutrition and immunization in rural India. Hopkins Population Center Papers on population WP 00-01.

Polissar, L., Severson, RK, and Brown, NK. (1987). Factors affecting place of death in Washington State, 1968-1981. J Community Health, 12(1):40-55.

Pritchard, RS., Fisher, ES., Teno, JM., Sharp, SM., Reding, DJ., Knaus, WA., Wennberg, JE., Lynn, J, for the SUPPORT Investigators. Influence of Patient Preferences and Local Health System Characteristics on the Place of Death. Journal of the American Geriatrics Society, 46: 1242-1250.

Rajeshwari, 1996. Gender bias in utilisation of health care facilities in rural Haryana.):, Economic and Political Weekly, 31(1): 489-494.

Saha, V., 2002. Salient Features of NSS Consumer Expenditure Surveys ( $51^{\text {st }}-54^{\text {th }}$ Rounds). India: Workshop on Poverty Measurement, Monitoring and Evaluation, January 11-12.

Sen, A., 1988. Family and food: Sex bias in poverty. In T. Srinivasan and P. Bardham (eds.) Rural Poverty in South Asia. New York: Columbia University Press.

, 1989. Women's Survival as a development problem. Bulletin of the American Academy of Arts and Sciences, 43:14-29.

, 1992. The World Health Report 1995, Bridging the Gaps. Geneva, World Health Organization.

Sood, A.K. and B.K. Nagla, 1994. The extent and pattern of utilisation of health services by rural women: A study in District Rohtak, Haryana. Indian Journal of Preventive Social Medicine, 25 (3\&4): 110-117.

Sudha, S., \& Arnold, SIR. (1999). Female Demographic Disadvantage in India 1981-1991: Sex Selective Abortions and Female Infanticide. Development and Change 30(3): 585 
UNICEF, 1990. The State of the World's Chikdren 1989. Oxford, Oxford University Press.

United Nations Development Program, 1995. Human Development Report 1995, UNDP New York, USA

United Nations, 1991. The world's women 1970-1990:trends and statistics, Social Statistics and Indicators Series, K. no 8, New York, UN.

Visaria, L., and P. Visaria, 1995. India’s Population in Transition. Population Bulletin 50(3).

Wadley, SS. (1993). Family Composition Strategies in Rural North India. Social Science and Medicine, 37(11): 1367-1376.

Waldron, I, 1995 Contributions of changing gender differentials in behaviour to changing gender differences in mortality. In D. Sabo and D. Gordon (eds) , Men's Health and Illness: gender, power and the body. London: Sage

Westerling, R. (1996). Can Regional Variation in "avoidable” mortality be explained by Deaths outside Hospital? A Study from Sweden, 1987-90. Journal of Epidemiology and Community Health, 50(3): 326-33.

WHO, 1946. Preamble to the Constitution of the World Health Organization as adopted by the International Health Conference, New York, 19-22 June, 1946; signed on 22 July 1946 by the representatives of 61 States (Official Records of the World Health Organization, no. 2, p. 100) and entered into force on 7 April 1948.

, 1992. Missing Women. British Medical Journal, 304:586-587.

,1998. Gender and Health. A Technical paper. http://www.who.int/frh-whd/index.html

, 2000. Women's Health in South-East Asia.

Wolfe, B.L., and J.R. Behrman, 1984. Determinants of Women's Health Status and Health-Care Utilization in a Developing Country: A Latent Variable Approach. Review of Economics and Statistics, 66 (4): 696-703. 
FIGURE 1. Percentage of children died in hospital by sex, age, and location

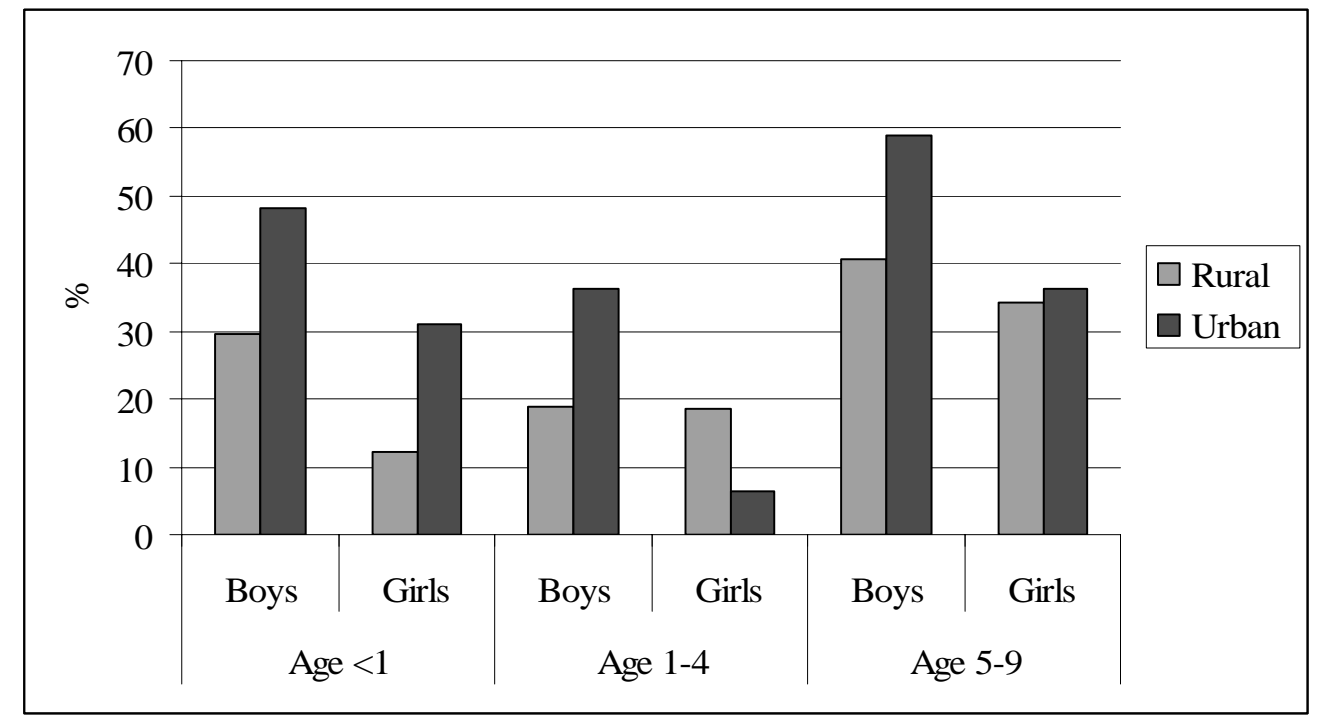


FIGURE 2. Percentage of children died in hospital by sex, age, and income quintile

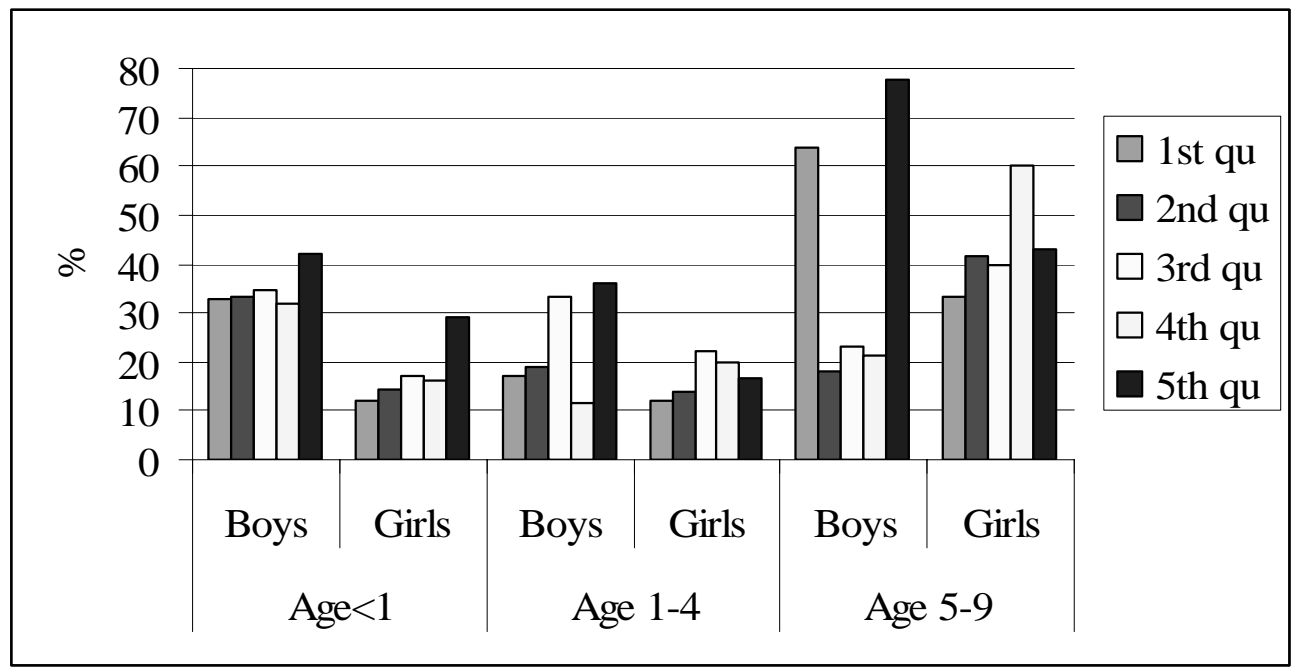


FIGURE 3. Probability of dying at different places as a function of age of the deceased child
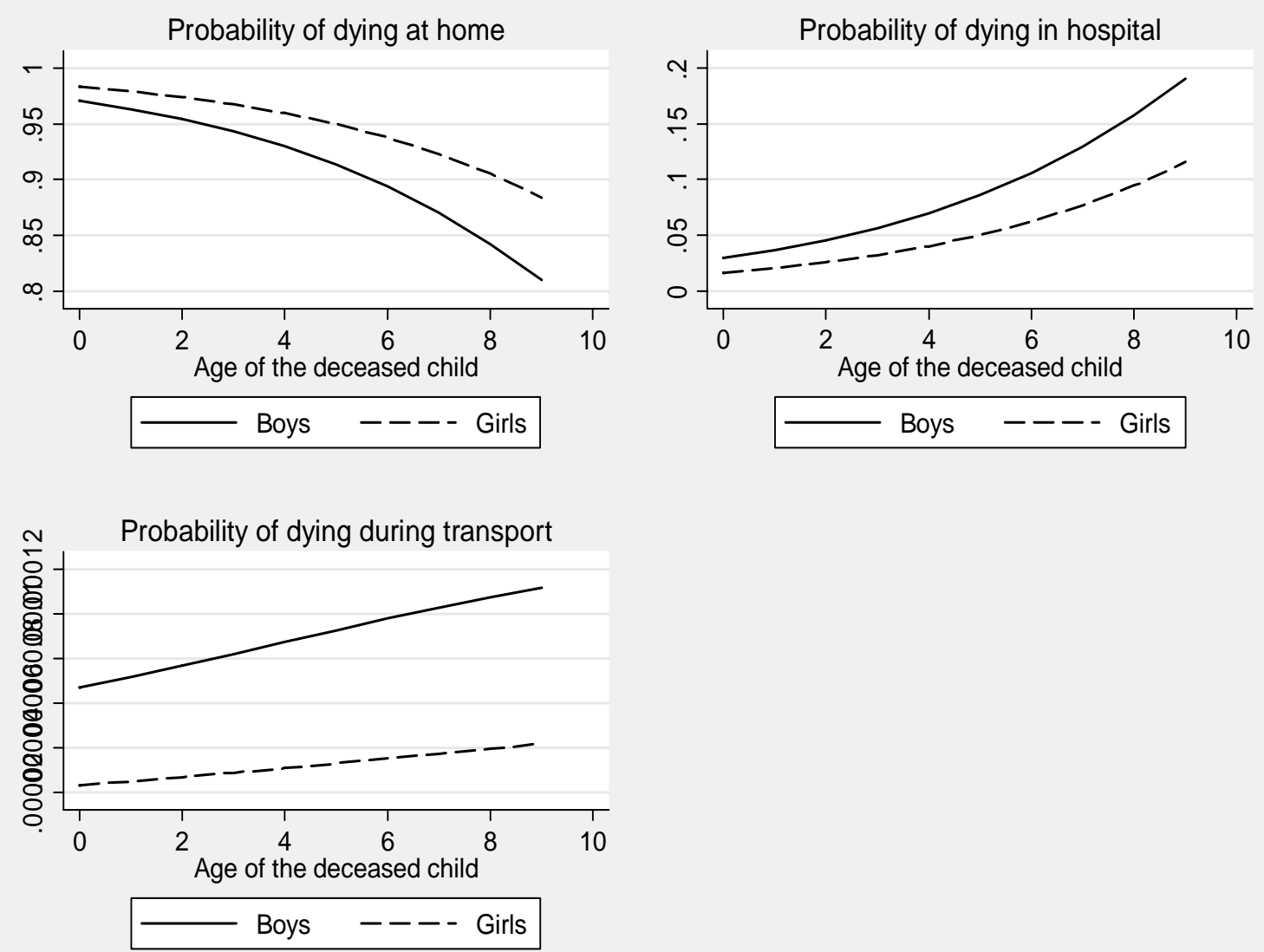
FIGURE 4. Probability of dying at different places as a function of age of number of female siblings
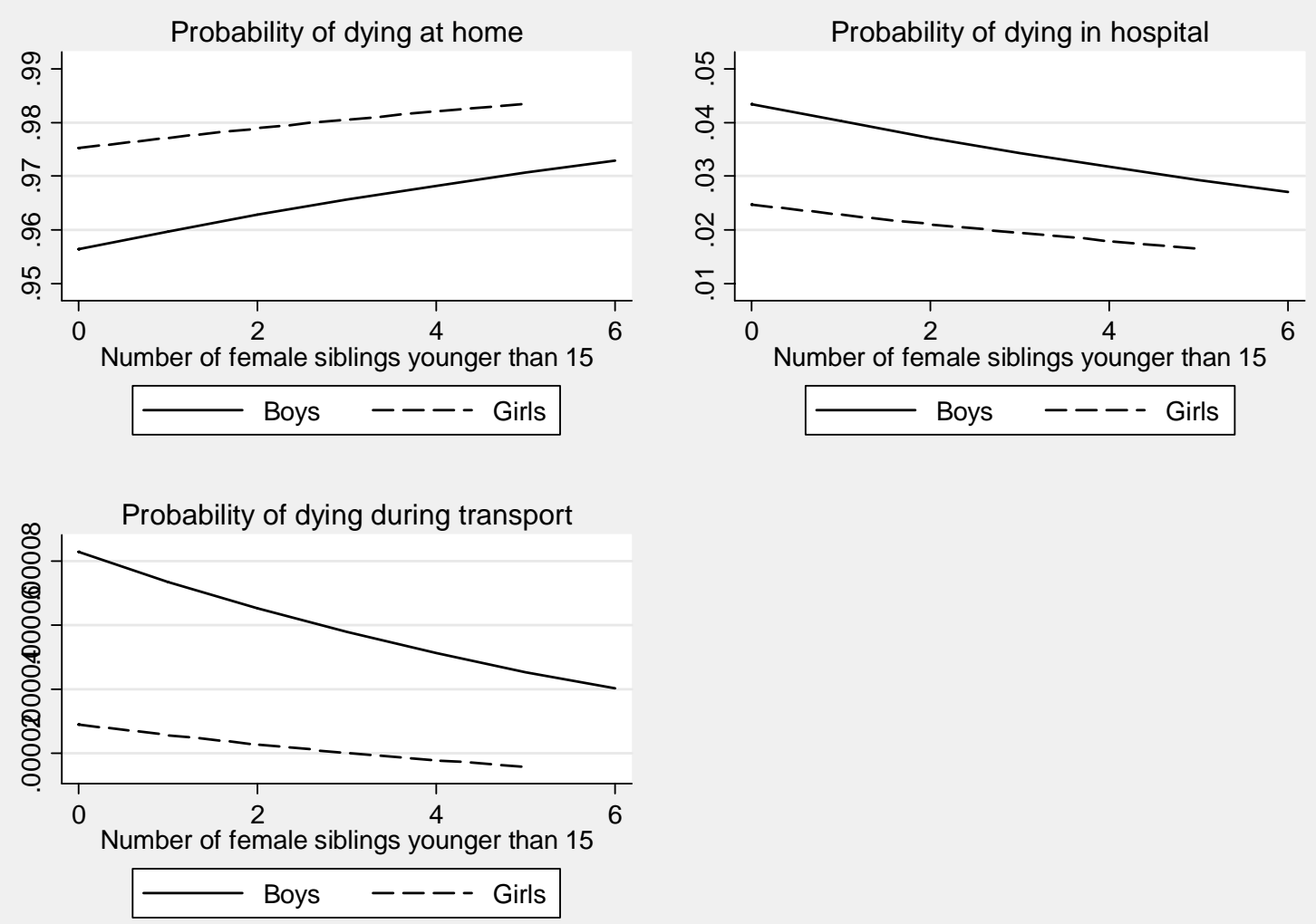
FIGURE 5. Probability of dying at different places as a function of age of the deceased child (interaction between age and gender included)
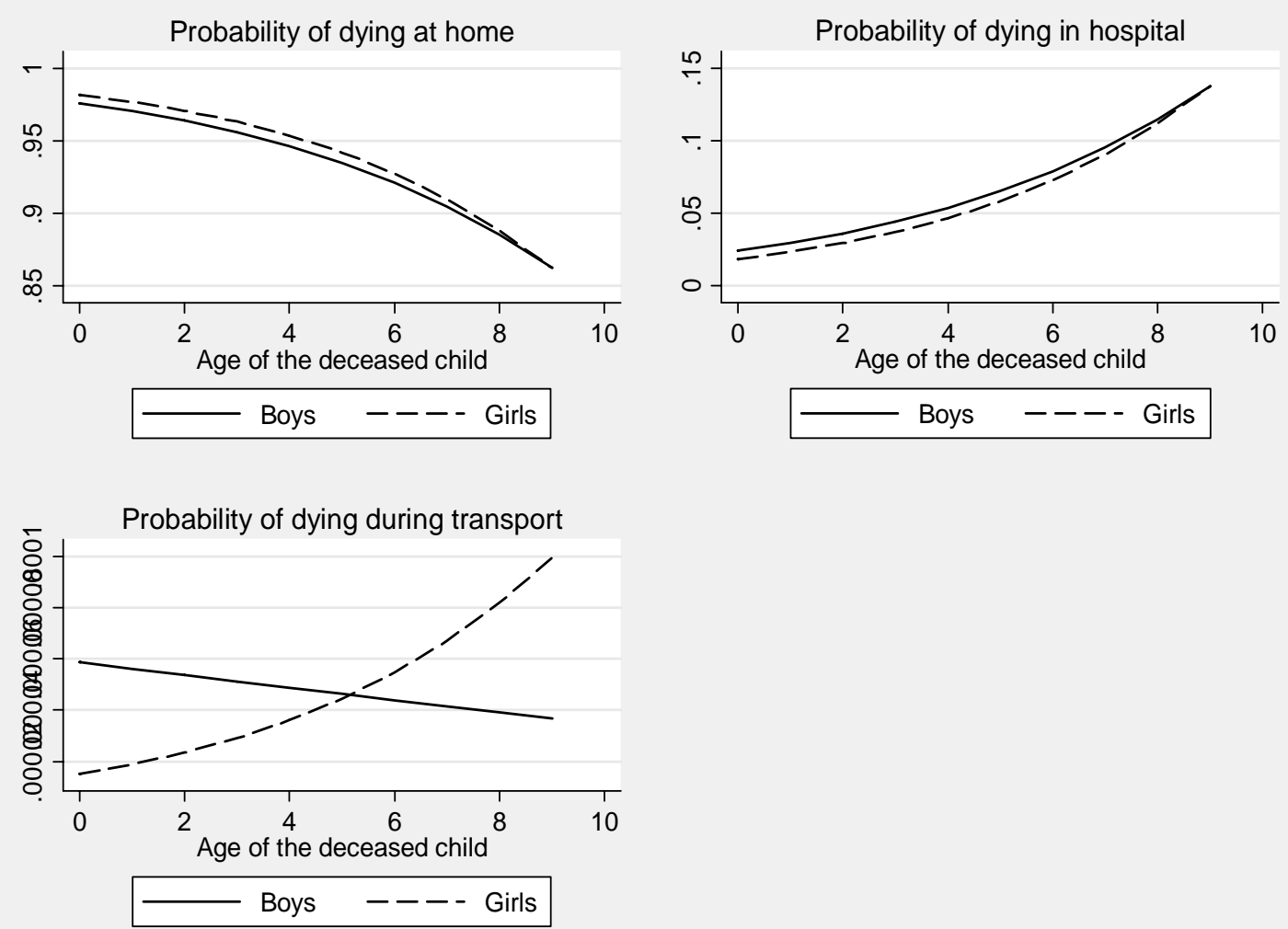
FIGURE 6. Probability of dying at different places as a function of number of female siblings (interaction between number of female siblings and gender included)
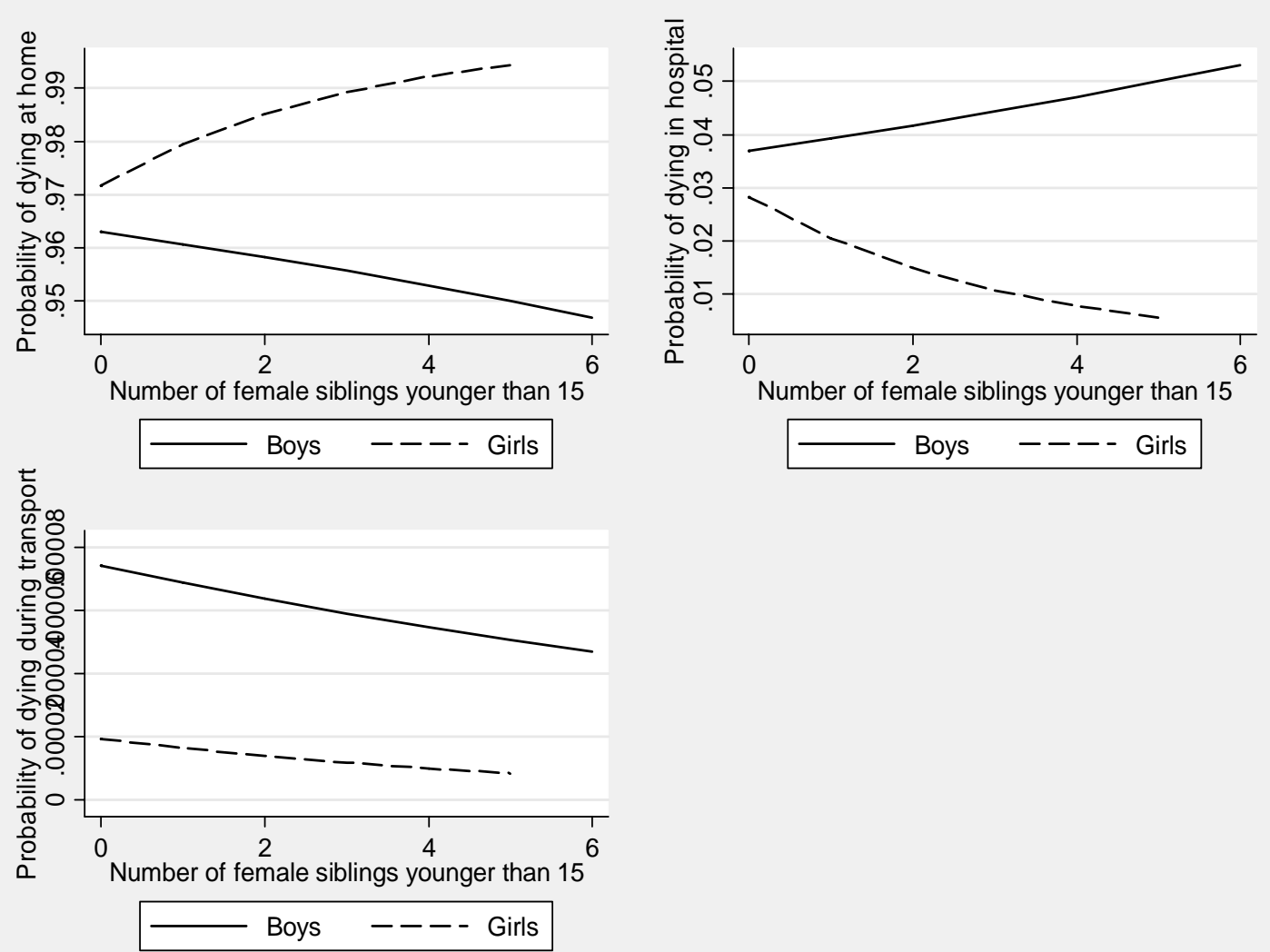
TABLE 1. Descriptive statistics

\begin{tabular}{lrr}
\hline Variable & Mean & SD \\
\hline Age of the head & 41.359 & 13.408 \\
Male headed households (1 if the head is male \& 0 otherwise) & 0.943 & 0.232 \\
Per capita expenditure (Rupee) & 43041.95 & 28461.02 \\
Location (1 = urban \& 0 otherwise) & 0.258 & 0.438 \\
Social status (1 if scheduled caste/tribes \& 0 otherwise) & 0.335 & 0.472 \\
Head's education (1 if completed primary \& above \& 0 otherwise) & 0.359 & 0.480 \\
Family size & 5.869 & 3.128 \\
Gender of the deceased child (1 if girl \& 0 otherwise) & 0.476 & 0.500 \\
Age of the deceased child & 1.442 & 2.249 \\
No of female siblings younger than 15 & 0.949 & 1.138 \\
\hline
\end{tabular}


TABLE 2. Place of death for different age group children by location, income, and gender

\begin{tabular}{|c|c|c|c|c|c|c|}
\hline \multirow{2}{*}{$\begin{array}{l}\text { Age } \\
\text { group }\end{array}$} & \multirow[b]{2}{*}{ Variable } & \multicolumn{5}{|c|}{ Place of death } \\
\hline & & At home & Hospital & $\begin{array}{l}\text { During } \\
\text { transport }\end{array}$ & $\begin{array}{l}\text { Other } \\
\text { places }\end{array}$ & $\begin{array}{l}\text { Pearson } \\
\text { chi }^{2}\end{array}$ \\
\hline \multirow{3}{*}{$<1$ year } & 1. Location & & & & & \multirow{3}{*}{$\begin{array}{l}21.49 * * * \\
(0.000)\end{array}$} \\
\hline & Rural & 72.48 & 21.80 & 2.45 & 3.27 & \\
\hline & Urban & 55.63 & 40.85 & 0.00 & 3.52 & \\
\hline \multirow[t]{2}{*}{$1-4$ years } & Rural & 74.78 & 18.70 & 1.74 & 4.78 & \multirow{2}{*}{$\begin{array}{l}6.78^{*} \\
(0.079)\end{array}$} \\
\hline & Urban & 67.69 & 21.54 & 7.69 & 3.08 & \\
\hline \multirow[t]{2}{*}{ 5-9 years } & Rural & 53.85 & 37.18 & 2.56 & 6.41 & \multirow{2}{*}{$\begin{array}{l}1.69 \\
(0.639)\end{array}$} \\
\hline & Urban & 42.86 & 50.00 & 3.57 & 3.57 & \\
\hline \multirow[t]{2}{*}{$0-9$ years } & Rural & 71.11 & 22.52 & 2.22 & 4.15 & \multirow{2}{*}{$\begin{array}{l}18.35^{* * *} \\
(0.000)\end{array}$} \\
\hline & Urban & 57.45 & 36.6 & 2.55 & 3.4 & \\
\hline \multirow{3}{*}{$<1$ year } & 2. Income & & & & & \multirow{3}{*}{$\begin{array}{l}15.33 \\
(0.224)\end{array}$} \\
\hline & $1^{\text {st }}$ quintile. & 69.67 & 22.95 & 1.64 & 5.74 & \\
\hline & $5^{\text {th }}$ quintile. & 58.06 & 36.56 & 1.08 & 4.30 & \\
\hline \multirow[t]{2}{*}{ 1-4 years } & $1^{\text {st }}$ quintile. & 77.46 & 14.08 & 1.41 & 7.04 & \multirow{2}{*}{$\begin{array}{l}16.04 \\
(0.189)\end{array}$} \\
\hline & $5^{\text {th }}$ quintile. & 69.77 & 27.91 & 0.00 & 2.33 & \\
\hline \multirow[t]{2}{*}{ 5-9 years } & $1^{\text {st }}$ quintile. & 45.00 & 50.00 & 5.00 & 0.00 & \multirow{2}{*}{$\begin{array}{l}11.59 \\
(0.479)\end{array}$} \\
\hline & $5^{\text {th }}$ quintile. & 37.50 & 62.50 & 0.00 & 0.00 & \\
\hline \multirow[t]{2}{*}{$0-9$ years } & $1^{\text {st }}$ quintile. & 69.95 & 22.54 & 1.88 & 5.63 & \multirow{2}{*}{$\begin{array}{l}19.06^{*} \\
(0.087)\end{array}$} \\
\hline & $5^{\text {th }}$ quintile. & 59.21 & 36.84 & 0.66 & 3.29 & \\
\hline & 3. Gender & & & & & \multirow{3}{*}{$\begin{array}{l}20.18^{* * *} \\
(0.000)\end{array}$} \\
\hline \multirow[t]{2}{*}{$<1$ year } & Girls & 77.33 & 17.33 & 2.22 & 3.11 & \\
\hline & Boys & 60.21 & 34.86 & 1.41 & 3.52 & \\
\hline \multirow[t]{2}{*}{$1-4$ years } & Girls & 77.56 & 16.03 & 2.56 & 3.85 & \multirow{2}{*}{$\begin{array}{l}3.208 \\
(0.361)\end{array}$} \\
\hline & Boys & 68.35 & 23.02 & 3.60 & 5.04 & \\
\hline \multirow[t]{2}{*}{ 5-9 years } & Girls & 53.85 & 34.62 & 5.77 & 5.77 & \multirow[t]{2}{*}{$\begin{array}{l}4.18 \\
(0.243)\end{array}$} \\
\hline & Boys & 48.15 & 46.30 & 0.00 & 5.56 & \\
\hline \multirow[t]{2}{*}{$0-9$ years } & Girls & 74.60 & 18.94 & 2.77 & 3.70 & \multirow[t]{2}{*}{$\begin{array}{l}23.37 * * * \\
(0.000)\end{array}$} \\
\hline & Boys & 61.22 & 32.70 & 1.89 & 4.19 & \\
\hline \multicolumn{2}{|c|}{ Girls * <1 year* female siblings } & 83.17 & 11.88 & 0.99 & 3.96 & \multirow[t]{2}{*}{$\begin{array}{l}17.56 \\
(0.001)\end{array}$} \\
\hline \multicolumn{2}{|c|}{ Boys*<1 year* girl siblings } & 60.36 & 36.04 & 1.80 & 1.80 & \\
\hline
\end{tabular}


TABLE 3. Determinants of place of death: Multinomial logistic regression results

\begin{tabular}{|c|c|c|c|c|c|}
\hline \multirow[t]{3}{*}{ Variable } & \multicolumn{5}{|c|}{ Place of death } \\
\hline & \multicolumn{2}{|c|}{ Hospital } & \multicolumn{2}{|c|}{ During transport } & \multirow{2}{*}{$\begin{array}{l}\text { At home } \\
\text { Marg eff. }\end{array}$} \\
\hline & Coeff. & Marg eff. & Coeff. & Marg eff. & \\
\hline \multirow[t]{2}{*}{ Age of the head } & 0.074 & & -0.001 & & \\
\hline & $(0.057)$ & & $(0.069)$ & & \\
\hline \multirow{2}{*}{ Age square of the head } & -0.001 & & -0.000 & & \\
\hline & $(0.001)$ & & $(0.001)$ & & \\
\hline \multirow[t]{2}{*}{ Male headed household } & 0.284 & & 0.051 & & \\
\hline & $(0.462)$ & & $(0.554)$ & & \\
\hline \multirow{2}{*}{ Ln per capita expenditure } & 0.241 & & -0.033 & & \\
\hline & $(0.241)$ & & $(0.288)$ & & \\
\hline \multirow[t]{2}{*}{ Location (1 = urban) } & 0.369 & & $0.621 * *$ & 0.00003 & -0.01211 \\
\hline & $(0.244)$ & & $(0.292)$ & & \\
\hline \multirow[t]{2}{*}{ Scheduled caste/tribes } & -0.079 & & 0.158 & & \\
\hline & $(0.250)$ & & $(0.293)$ & & \\
\hline \multirow{2}{*}{$\begin{array}{l}\text { Head's education(1 if completed primary } \\
\text { and above) }\end{array}$} & $0.508^{* *}$ & 0.0163 & $0.939 * * *$ & 0.00005 & -0.01644 \\
\hline & $(0.217)$ & & $(0.260)$ & & \\
\hline \multirow[t]{2}{*}{ Ln family size } & 0.031 & & -0.123 & & \\
\hline & $(0.219)$ & & $(0.261)$ & & \\
\hline \multirow[t]{2}{*}{ Age of the deceased child } & $0.227 * * *$ & 0.0068 & 0.077 & & -0.00681 \\
\hline & $(0.042)$ & & $(0.061)$ & & \\
\hline \multirow[t]{2}{*}{ Num. of female siblings younger than 15} & -0.082 & & -0.123 & & \\
\hline & $(0.101)$ & & $(0.122)$ & & \\
\hline \multirow[t]{2}{*}{ Gender of the deceased child (1 if girl) } & $-0.584 * * *$ & $0-.0174$ & $-1.071 * * *$ & -0.00005 & 0.01748 \\
\hline & $(0.208)$ & & $(0.268)$ & & \\
\hline \multicolumn{6}{|l|}{70 district level dummy variables } \\
\hline \multirow[t]{2}{*}{ Constant } & $-5.433^{*}$ & & -0.465 & & \\
\hline & $(3.044)$ & & $(3.658)$ & & \\
\hline Observations & & & 907 & & \\
\hline Log likelihood & & & -563.35478 & & \\
\hline LR chi2(158) & & & 299.81 & & \\
\hline Prob > chi2 & & & 0.0000 & & \\
\hline Pseudo R2 & & & 0.2102 & & \\
\hline
\end{tabular}

Standard errors in parentheses

* Significant at $10 \%$; ** significant at 5\%; *** significant at $1 \%$ 
TABLE 4. Determinants of place of death with interaction variables: Multinomial logistic regression results

\begin{tabular}{|c|c|c|}
\hline \multirow[t]{2}{*}{ Variable } & \multicolumn{2}{|c|}{ Place of death } \\
\hline & Hospital & During transport \\
\hline \multirow[t]{2}{*}{ Age of the head } & 0.073 & 0.009 \\
\hline & $(0.057)$ & $(0.069)$ \\
\hline \multirow[t]{2}{*}{ Age square of the head } & -0.001 & -0.000 \\
\hline & $(0.001)$ & $(0.001)$ \\
\hline \multirow[t]{2}{*}{ Male headed households } & 0.283 & 0.127 \\
\hline & $(0.465)$ & $(0.567)$ \\
\hline \multirow[t]{2}{*}{ Ln per capita expenditure } & 0.210 & -0.022 \\
\hline & $(0.243)$ & $(0.292)$ \\
\hline \multirow[t]{2}{*}{ Location (1 = urban) } & 0.365 & $0.647 * *$ \\
\hline & $(0.246)$ & $(0.294)$ \\
\hline \multirow[t]{2}{*}{ Scheduled caste/tribes } & -0.092 & 0.135 \\
\hline & $(0.250)$ & $(0.295)$ \\
\hline \multirow[t]{2}{*}{ Head's education ( 1 if completed primary and above) } & $0.492 * *$ & $0.897 * * *$ \\
\hline & $(0.218)$ & $(0.261)$ \\
\hline \multirow[t]{2}{*}{ Ln family size } & 0.027 & -0.120 \\
\hline & $(0.220)$ & $(0.263)$ \\
\hline \multirow[t]{2}{*}{ Gender of the deceased child ( 1 if girl) } & -0.277 & $-1.355^{* * *}$ \\
\hline & $(0.303)$ & $(0.388)$ \\
\hline \multirow[t]{2}{*}{ Age of the deceased child } & $0.208 * * *$ & -0.038 \\
\hline & $(0.057)$ & $(0.087)$ \\
\hline \multirow[t]{2}{*}{ Gender $\mathrm{X}$ age of the deceased child } & 0.031 & $0.261 * *$ \\
\hline & $(0.082)$ & $(0.121)$ \\
\hline \multirow[t]{2}{*}{ No of female siblings younger than 15} & 0.063 & -0.073 \\
\hline & $(0.123)$ & $(0.143)$ \\
\hline \multirow[t]{2}{*}{ Gender X Number of female siblings younger than 15} & $-0.393^{*}$ & -0.098 \\
\hline & $(0.200)$ & $(0.256)$ \\
\hline \multicolumn{3}{|l|}{70 district level dummy variables } \\
\hline \multirow[t]{2}{*}{ Constant } & $-5.158 *$ & -0.733 \\
\hline & $(3.067)$ & (3.709) \\
\hline Observations & \multicolumn{2}{|c|}{907} \\
\hline Log likelihood & \multicolumn{2}{|c|}{-559.01} \\
\hline LR chi' ${ }^{2}$ (162) & \multicolumn{2}{|c|}{308.49} \\
\hline Prob > chi2 & \multicolumn{2}{|c|}{0.0000} \\
\hline Pseudo R2 & \multicolumn{2}{|c|}{0.2163} \\
\hline
\end{tabular}

Standard errors in parentheses

* significant at 10\%; ** significant at 5\%; *** significant at $1 \%$ 
TABLE 5. Robustness test

\begin{tabular}{|c|c|c|c|}
\hline \multirow[t]{2}{*}{ Explanatory variable } & \multicolumn{3}{|c|}{ Dependent variable } \\
\hline & $\begin{array}{l}\text { Hospitalization } \\
\text { before death } \\
\text { (Logit results) }\end{array}$ & $\begin{array}{l}\text { No medical } \\
\text { attention before } \\
\text { death } \\
\text { (Logit results) }\end{array}$ & $\begin{array}{l}\text { Number of } \\
\text { times } \\
\text { hospitalized } \\
\text { before death } \\
\text { (OLS results) }\end{array}$ \\
\hline Age of the household head & $\begin{array}{l}0.060 \\
(0.045)\end{array}$ & $\begin{array}{l}-0.029 \\
(0.041)\end{array}$ & $\begin{array}{l}0.012 \\
(0.009)\end{array}$ \\
\hline Age square of the household head & $\begin{array}{l}-0.001 \\
(0.000)\end{array}$ & $\begin{array}{l}0.000 \\
(0.000)\end{array}$ & $\begin{array}{l}-0.000 \\
(0.000)\end{array}$ \\
\hline Female headed household & $\begin{array}{l}0.458 \\
(0.380)\end{array}$ & $\begin{array}{l}-0.263 \\
(0.361)\end{array}$ & $\begin{array}{l}0.004 \\
(0.082)\end{array}$ \\
\hline Ln per capita expenditure & $\begin{array}{l}0.173 \\
(0.193)\end{array}$ & $\begin{array}{l}-0.641^{* * *} \\
(0.208)\end{array}$ & $\begin{array}{l}-0.023 \\
(0.044)\end{array}$ \\
\hline Location $(1=$ urban $)$ & $\begin{array}{l}0.451^{* *} \\
(0.197)\end{array}$ & $\begin{array}{l}-0.456^{* *} \\
(0.225)\end{array}$ & $\begin{array}{l}0.118^{* *} \\
(0.047)\end{array}$ \\
\hline Scheduled caste/tribes & $\begin{array}{l}0.010 \\
(0.198)\end{array}$ & $\begin{array}{l}0.152 \\
(0.194)\end{array}$ & $\begin{array}{l}-0.038 \\
(0.045)\end{array}$ \\
\hline $\begin{array}{l}\text { Head's education( } 1 \text { if completed primary and } \\
\text { above) }\end{array}$ & $\begin{array}{l}0.247 \\
(0.177)\end{array}$ & $\begin{array}{l}0.048 \\
(0.186)\end{array}$ & $\begin{array}{l}0.114^{* * *} \\
(0.041)\end{array}$ \\
\hline Ln family size & $\begin{array}{l}0.054 \\
(0.177)\end{array}$ & $\begin{array}{l}-0.145 \\
(0.181)\end{array}$ & $\begin{array}{l}0.004 \\
(0.040)\end{array}$ \\
\hline Age of the deceased child & $\begin{array}{l}0.174 * * * \\
(0.037)\end{array}$ & $\begin{array}{l}-0.020 \\
(0.039)\end{array}$ & $\begin{array}{l}0.048^{* * *} \\
(0.009)\end{array}$ \\
\hline Number of female siblings younger than 15 & $\begin{array}{l}-0.050 \\
(0.078)\end{array}$ & $\begin{array}{l}-0.059 \\
(0.082)\end{array}$ & $\begin{array}{l}-0.014 \\
(0.018)\end{array}$ \\
\hline Gender & $\begin{array}{l}-0.637^{* * *} \\
(0.167)\end{array}$ & $\begin{array}{l}-0.059 \\
(0.167)\end{array}$ & $\begin{array}{l}-0.114^{* * *} \\
(0.038)\end{array}$ \\
\hline Constant & $\begin{array}{l}-3.613 \\
(2.442)\end{array}$ & $\begin{array}{l}6.407 * * \\
(2.562)\end{array}$ & $\begin{array}{l}0.450 \\
(0.556)\end{array}$ \\
\hline Pseudo $\mathrm{R}^{2} / \mathrm{R}^{2}$ & 0.14 & 0.09 & 0.20 \\
\hline
\end{tabular}

Standard errors in parentheses

* Significant at $10 \%$; ** significant at $5 \%$; *** significant at $1 \%$ 


\footnotetext{
${ }^{1}$ The only exception in this area was the work of Gupta and Sankar (20002). However, the main focus of the study was on various factors that affect lack of medical attention before death. As a result gender did not get enough attention and the interaction of gender with other variables was not examined. Moreover, the study took only one indicator (medical attention before death) in the analysis.

${ }^{2}$ See for instance, Westerling, 1996; Axelsson and Christensen, 1996; Polissar et al., 1987;

Pritchard, et al., 1998; Costantini et al., 2000; Feudtner et al., 2002, Lock and Higginson, 2005.

${ }^{3}$ We use the xi3 command available in STATA.

${ }^{4}$ Gupta and Sankar (2002) also found insignificant coefficient for sex using the same data set and indicator. Their results showed that gender did not make a difference in getting medical attention before death.
} 